\title{
Erythrocytes' Detoxifying and Anti-oxidant capabilities in Human Fascioliasis: Effect of Egaten
}

\author{
Ebied SA*, Farag $\mathrm{HF}^{* *}$, Youssef $A I^{*}$, Ossman $M M^{* *}$, \\ EL-Samak $M Y^{* * *}$ and Hassnian NA* \\ Departments of Applied Medical Chemistry*, Parasitology** and Chemical \\ Pathology*** Medical Research Institute, Alexandria University
}

\begin{abstract}
The present study was carried out on 21 fasciolia patients (6 with acute fascioliasis and 15 with chronic fascioliasis), and 10 age matched controls. Specific activities of superoxide dismutase (SOD), catalase (CAT), glutathione peroxidase $\left(G P_{X}\right)$, glutathione reductase (GR), glutathione S-transferase (GST), glucose 6-phosphate dehydrogenase (G6-PD) as well as glutathione content (GSH) were measured in red blood cells as it offers a number of advantage for studying the effects of oxidants. Egaten (the human form of the fasciolocidal drug Triclabendazole) was supplemented to all patients in a dose of $10 \mathrm{mg} / \mathrm{kg}$ body weight for 2 successive days. Before treatment specific activities of SOD, GP $, G R, G 6-P D$ and GSH content were significantly reduced in the erythrocytes of all patients. The only exception was CAT enzyme that didn't show any significant difference from controls and GST that showed significant elevation. Liver function tests were significantly elevated in plasma of fasicola patients. After treatment the level of all studied parameters except CAT were significantly elevated than that before treatment and became more or less round the figures of controls. Liver function tests became normal again, and anemia was recovered. Conclusively, Egaten has cured all cases of fascioliasis under study and it has abolished the effect of the parasite's oxidants on the antioxidant capabilities of erythrocytes.
\end{abstract}

\section{INTRODUCTION}

Since more than two decades, fascioliasis has emerged as a human infection. That parasite affects the liver particularly during the acute stage, when the juvenile flukes migrate through the liver parenchyma, causing lysis of the liver tissue ${ }^{(1)}$. Severe immunological and inflammatory reactions were observed during that stage, as the excretory, secretory products of the worms were in direct contact with the tissues ${ }^{(2)}$.
During the chronic stage, the worms were present in the bile ducts and gall bladder, the epithelium of the biliary system shows inflammation and hyperplasia ending in an obstructive phase $^{(3)}$.

Infection with that parasite leads to an intimate contact between the parasite and the host immune system. Neutrophils, eosinophils and macrophages play an important role in defense against the parasite ${ }^{(2,4)}$. The initial reaction of these cells is the generation of reactive oxygen species $(\mathrm{ROS})^{(5)}$. ROS generation, through 
normal cellular metabolism and by means of exogenous insult is a constant problem, for which cells have developed multiple protective mechanisms ${ }^{(\mathbf{6})}$. Central to that defense are the anti-oxidant enzymes of the blood. These include SOD, $\mathrm{GP}_{\mathrm{X}}, \mathrm{CAT}$, the detoxifying enzyme GST, as well as the enzymes involved in recycling the oxidized GSH such as GR and G6$\mathrm{PD}^{(7)}$. Red blood cells could be regarded as circulating anti-oxidant carriers; they offer a number of advantages for studying the effects of oxidants ${ }^{(\mathbf{8})}$.

TCBZ (6-chloro-5 [2, 3 dichlorophenoxy]-2- methylenebenzimidazole) has been extensively used in the treatment of animal fasciolasis $^{\left({ }^{(9)}\right.}$, Egaten, a form of TCBZ, specially prepared for human use proved safe against fasciolasis. That drug has the advantage of treating both acute and chronic fasciolasis.

The aim of the present work was to study the effect of fasciola infection, acute and chronic, on the activities of some erthrocytes' detoxifying and anti-oxidant enzymes. Besides, the effect of Egaten on these enzymes was assessed after three months from treatment.

\section{MATERIALS \& METHODS}

The present study was carried on 21 patients $15-30$ years old classified into the following groups:

Group I: Six patients with acute fasciolasis diagnosed clinically by fever, abdominal pain and enlarged liver, haematologically by eosenophilia and serologically by a positive indirect haemagglutination test (titre $>1 / 640$ ).

Group II: Fifteen patients with chronic fascioliasis passing eggs in the stools and diagnosed by the kato katz technique ${ }^{(10)}$. Control group of ten healthy persons; age matched were chosen.

None of the patients and controls had received blood transfusion, antibiotics or medication at least three months before the study. None gave a history of jaundice, diabetes mellitus or chronic diseases.

\section{Regimen of treatment}

Egaten (Novartis, Pharma AG, Bale, Switzerland) was given to all patients in a dose of $10 \mathrm{mg} / \mathrm{kg}$ body weight for two successive days after intake of a fatty meal (as recommended by the manufacturer) ${ }^{(\mathbf{1 1})}$.

After the end of therapy, patients were followed up every fortnight for a period of 3 months to check the presence of eggs in stools; IHAT was repeated for patients with acute fascioliasis after 3 months.

\section{Blood sampling}

Ten mls. venous blood, were withdrawn from all patients before and 3 months after treatment, and from the control group. $200 \mu \mathrm{l}$ were immediately used for assay of GSH. One $\mathrm{ml}$ was dispatched into a heparinized tube for studying the blood picture ${ }^{(\mathbf{1 2})}$. The remaining blood sample was pipetted into tubes containing $10 \mathrm{mM}$ (EDTA). Within 4 hours, the blood was centrifuged at $3000 \mathrm{rpm}$ for 20 minutes in a cooling centrifuge to separate the plasma for assessment of liver function tests (ALT, $\mathrm{AST}^{(\mathbf{1 3})}, \mathrm{ALP}^{(14)}$, Bilirubin ${ }^{(15)}$. The Buffy coat was removed and the remaining erythrocytes were drawn and washed 3 times in cold sterile saline and used for assaying the activities of the different enzymes. $\mathrm{SOD}^{(16)}, \mathrm{CAT}^{(17)}, \mathrm{GSH}^{(18)}, \mathrm{GPx}^{(19)}$, $\mathrm{GR}^{(\mathbf{2 0})}$, $\mathrm{GST}^{(\mathbf{2 1})}$, G6-PD ${ }^{(\mathbf{2 2})}$, protein 
content by Lowery $\mathrm{OH}$ et al. ${ }^{(23)}$ and $\mathrm{Hb}^{(24)}$.

Statistical analysis was done using SPSS8/ windows. Student " $\mathrm{t}$ " test, paired " $t$ " test and ANOVA test were used to compare means of different variance. Difference was considered significant at $\mathrm{p}<0.05$.

\section{RESULTS}

\section{I- Parasitological results}

All cases of acute fascioliasis revealed a drop in eosinophilia and in the IHA titres after treatment confirming their cure. Chronic cases ceased to pass ova in the stools and the cure rate was $100 \%$

\section{II- Biochemical results}

Results of the present study revealed that the specific activities of $\mathrm{Cu} / \mathrm{Zn}-\mathrm{SOD}, \mathrm{GP}_{\mathrm{x}}$, GR, G6-PD as well as GSH content were significantly reduced when compared with controls in the erythrocytes of patients with acute and chronic fascioliasis before treatment, $(\mathrm{P}=$ $0.045, \mathrm{P}=0.001, \mathrm{P}=0.032, \mathrm{P}=0.009$, $\mathrm{P}=0.043)$ for acute fasciolasis and $(\mathrm{P}$ $=0.000, \mathrm{P}=0.001, \mathrm{P}=0.001, \mathrm{P}=$ $0.000, \quad \mathrm{P}=0.019$ ) for chronic fasciloiasis respectively (Tables I-V). The only exception of these was GST specific activity which showed significant increase in acute and chronic fascioliasis when compared with controls before treatment $(\mathrm{P}=$ $0.001, \mathrm{P}=0.000$ ) respectively (Table VI).

Catalase specific activity in both acute and chronic fascioliasis didn't show any significant difference before treatment when compared with controls $\quad(\mathrm{P}=0.105, \quad \mathrm{P}=0.300)$ respectively (Table VII).
Enzyme activities of $\mathrm{GP}_{\mathrm{X}}, \mathrm{GR}$, GST and GSH level didn't show significant difference in acute stage of fascioliasis when compared with chronic stage $(\mathrm{P}>0.05)$.

On the other hand, SOD, CAT and $\mathrm{G}_{\mathrm{x}} 6$-PD activities were significantly higher in acute stage of the disease when compared with the chronic stage $(\mathrm{P}=0.01, \quad \mathrm{P}=0.001$, $\mathrm{P}=0.001)$ respectively.

After 3 months of Egaten treatment, specific activities of SOD, $\mathrm{GP}_{\mathrm{x}}, \mathrm{GR}, \mathrm{G6}-\mathrm{PD}$ as well as GSH level were significantly elevated in both acute fascioliasis $(\mathrm{P}=0.001, \mathrm{P}=0.000$, $\mathrm{P}=0.006, \quad \mathrm{P}=0.022, \quad \mathrm{P}=0.015) \quad$ and chronic fascioliasis $\quad(\mathrm{P}=0.000$, $\mathrm{P}=0.001, \mathrm{P}=0.000, \mathrm{P}=0.000, \mathrm{P}=0.000$ ) respectively, when compared with that before treatment and all became around the figures of normal controls (Tables I-V). Erythrocyte GST mean activity in both studied groups was significantly lower than that before treatment $\quad(\mathrm{P}=0.022, \quad \mathrm{P}=0.000)$ respectively and regained its normal value (Table VI). Regarding catalase specific activity after 3 months of Egaten treatment showed significant elevation when compared with that before treatment $(\mathrm{P}=0.003, \mathrm{P}=0.000)$ respectively and, also, with that of control $\quad(\mathrm{P}=0.000, \quad \mathrm{P}=0.004)$ respectively (Table VII).

\section{III- Haematological results}

In comparison with control group, $\mathrm{Hb}$ content in acute and chronic fascioliasis was significantly lower $(\mathrm{P}$ $=0.000$ and $\mathrm{P}=0.000)$. After 3 months of Egaten treatment, $\mathrm{Hb}$ content was significantly elevated than that before treatment $(\mathrm{P}=0.000$, $\mathrm{P}=0.000)$ and became within the normal range of control. Heamatocruit 
values was significantly lower in the two studied groups when compared with controls $(\mathrm{P}=0.002, \mathrm{P}=0.000)$ but after treatment with Egaten it regained its normal value. The same result was detected in red blood cells count which showed significant decrease in both patients with acute and chronic fascioliasis $(\mathrm{P}=0.000, \mathrm{P}$ $=0.000)$. After 3 months of Egaten treatment the count increased to show significant elevation than that of before treatment $(\mathrm{P}=0.000, \mathrm{P}=0.000)$ respectively and to become within the normal range of control.

Before treatment eosiphilic \% was significantly higher in patients with acute and chronic fascioliasis when compared with control $(\mathrm{P}=0.000, \mathrm{P}=$ $0.000)$ respectively. After Egaten treatment it was significantly decreased than before treatment $(\mathrm{P}=0.001, \mathrm{P}=$ 0.000 ) and regained its normal level only in patients with chronic fascioliasis $(\mathrm{P}=0.132)$, but remained significantly higher than control in patients with acute fascioliasis $(\mathrm{P}=0.008)$ (Table VIII).

\section{IV-Liver function tests}

Enzyme activity of both ALT and AST were significantly elevated in acute fascioliasis only but not in chronic fascioliasis when compared with controls. $(\mathrm{P}=0.001, \mathrm{P}=0.001)$ for acute stage, but $(\mathrm{P}=0.726, \mathrm{P}=$ 0.524 ) for chronic stage.

After 3 months of Egaten treatment the activities of the two enzymes in acute fascioliasis were significantly decreased when compared with that before treatment $(\mathrm{P}=0.011, \mathrm{P}=0.020$, respectively) and regained the normal values. No significant change was noticed in case of chronic fascioliasis.

ALP specific activity was significantly elevated in both patients with acute and chronic fascioliasis when compared with control $(\mathrm{P}=$ $0.001, \mathrm{P}=0.011)$. After treatment the plasma level of the enzyme was statistically decreased in both groups $(\mathrm{P}=0.000, \mathrm{P}=0.000)$ than that before treatment and returned to the normal values.

Bilirubin level in acute and chronic fascioliasis was significantly elevated when compared with control $(\mathrm{P}=0.006, \mathrm{P}=0.002)$. After treatment the level decreased significantly when compared with that before treatment $(\mathrm{P}=0.001, \mathrm{P}=$ $0.000)$ and became within the normal range. 
Table (I): Erythrocyte superoxide dismutase specific activity of controls and patients infected with Fasciola before and after treatment with Egaten.

\begin{tabular}{|c|c|c|c|c|c|}
\hline & \multirow{2}{*}{$\begin{array}{l}\text { Control } \\
\text { group }\end{array}$} & \multicolumn{2}{|c|}{ Acute Fasciola patients } & \multicolumn{2}{|c|}{ Chronic Fasciola patients } \\
\hline & & $\begin{array}{c}\text { Before } \\
\text { treatment }\end{array}$ & $\begin{array}{c}\text { After } \\
\text { treatment }\end{array}$ & $\begin{array}{c}\text { Before } \\
\text { treatment }\end{array}$ & $\begin{array}{c}\text { After } \\
\text { treatment }\end{array}$ \\
\hline $\mathbf{n}$ & $(10)$ & $(6)$ & $(6)$ & $(15)$ & $(15)$ \\
\hline Range & $10.91-27.43$ & $6.25-16.83$ & $17.24-21.55$ & $2.32-18.71$ & $9.02-24.24$ \\
\hline \multirow[t]{6}{*}{$\begin{array}{l}\text { Mean } \pm \\
\text { S.E.M }\end{array}$} & $18.14 \pm 1.66$ & $12.78 \pm 1.43$ & $19.21 \pm 0.56$ & $8.55 \pm 1.41$ & $19.36 \pm 0.87$ \\
\hline & & $\diamond \quad P$ & $0.001 \uparrow$ & $\diamond$ & .000 \\
\hline & & $\mathbf{P}=\mathbf{0 . 0 4 5} \downarrow$ & & & \\
\hline & & $P=0.635$ & & & \\
\hline & & $\mathrm{P}=\mathbf{0 . 0 0 0}$ & & & \\
\hline & & $\mathrm{P}=\mathbf{0 . 4 8 3}$ & & & \\
\hline
\end{tabular}

The results are expressed in $\mathrm{U} / \mathrm{gHb}$.

Table (II): Erythrocyte glutathione peroxidase specific activity of controls and patients infected with Fasciola before and after treatment with Egaten.

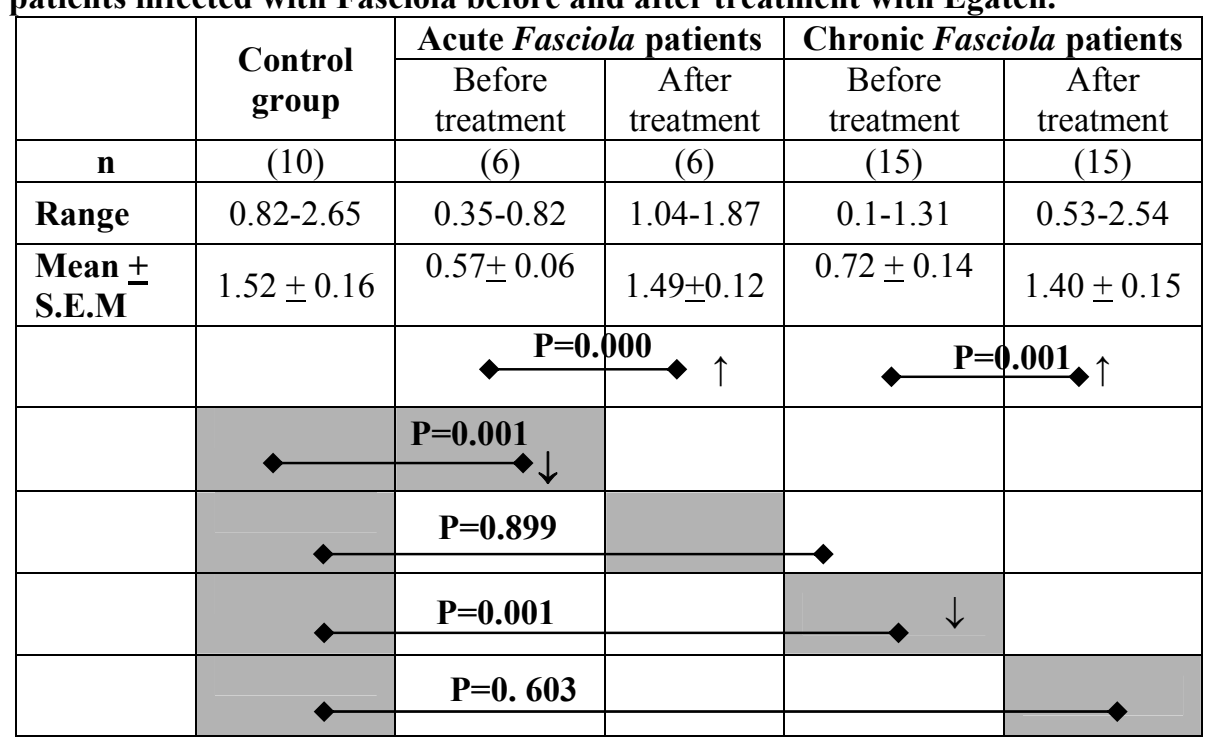

The results are expressed in $\mathrm{U} / \mathrm{gHb}$ 
Table (III): Erythrocyte glutathione reductase specific activity of controls and patients infected with Fasciola before and after treatment with Egaten.

\begin{tabular}{|c|c|c|c|c|c|}
\hline & \multirow{2}{*}{$\begin{array}{l}\text { Control } \\
\text { group }\end{array}$} & \multicolumn{2}{|c|}{ Acute Fasciola patients } & \multicolumn{2}{|c|}{ Chronic Fasciola patients } \\
\hline & & $\begin{array}{c}\text { Before } \\
\text { treatment }\end{array}$ & $\begin{array}{c}\text { After } \\
\text { treatment }\end{array}$ & $\begin{array}{l}\text { Before } \\
\text { treatment }\end{array}$ & $\begin{array}{c}\text { After } \\
\text { treatment }\end{array}$ \\
\hline $\mathbf{n}$ & $(10)$ & $(6)$ & $(6)$ & $(15)$ & $(15)$ \\
\hline Range & $3.10-7.91$ & $2.09-3.20$ & $2.21-6.50$ & $1.49-5.87$ & $2.70-12.43$ \\
\hline \multirow[t]{6}{*}{$\begin{array}{l}\text { Mean } \pm \\
\text { S.E.M }\end{array}$} & $4.29 \pm 0.43$ & $2.93 \pm 0.17$ & $5.19 \pm 0.64$ & $2.61 \pm 0.25$ & $5.50 \pm 0.69$ \\
\hline & & $P=0$ & $\rightarrow \uparrow$ & & .000 \\
\hline & & $\mathrm{P}=\mathbf{0 . 0 3 2} \downarrow$ & & & \\
\hline & $\bullet$ & $\mathrm{P}=\mathbf{0 . 2 4 7}$ & & $\bullet$ & \\
\hline & $\diamond$ & $P=0.001$ & & & \\
\hline & $\diamond$ & $P=0.201$ & & & \\
\hline
\end{tabular}

The results are expressed in $\mathrm{U} / \mathrm{gHb}$.

Table (VI): Erythrocyte glucose 6-phosphate dehydrogenase specific activity of controls and patients infected with Fasciola before and after treatment with Egaten.

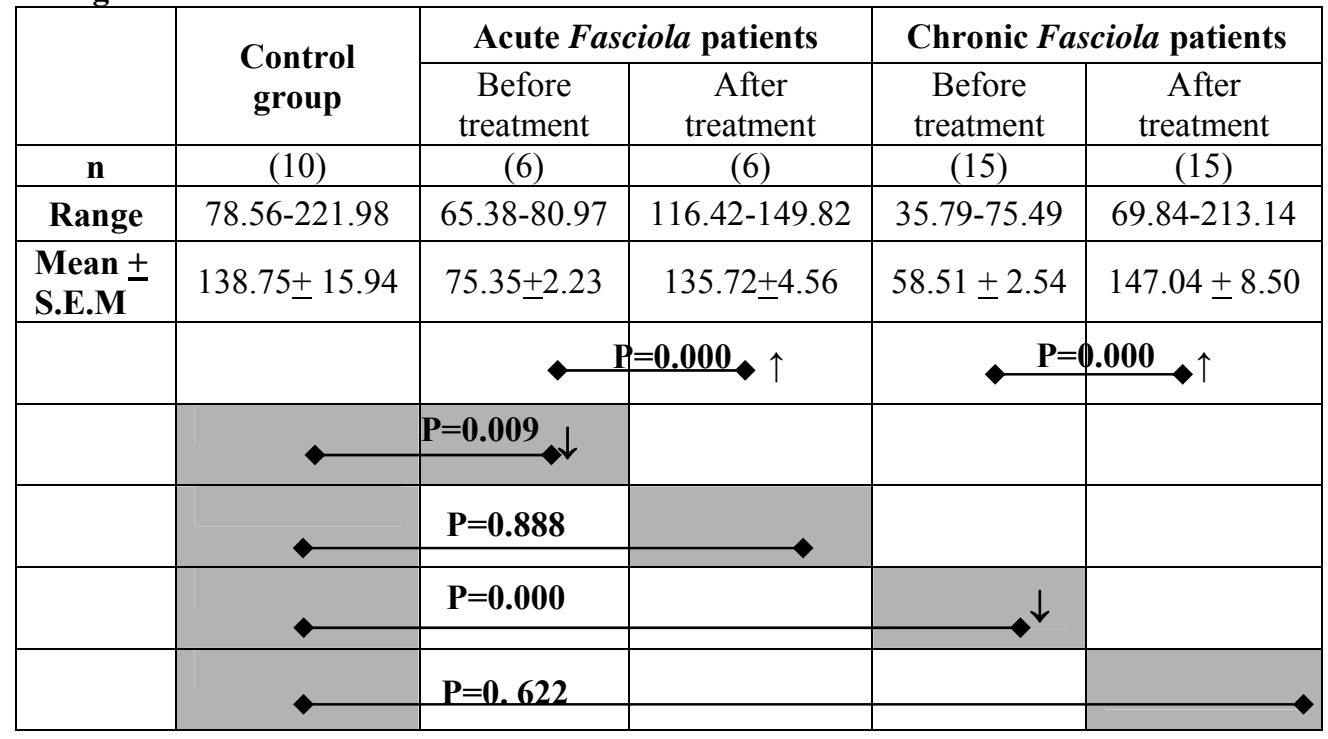

The results are expressed in $\mathrm{Ul} \mathbf{g ~ H b}$ 
Table (V): Erythrocyte glutathione contents of controls and patients infected with Fasciola before and after treatment with Egaten.

\begin{tabular}{|c|c|c|c|c|c|}
\hline & \multirow[b]{2}{*}{$\begin{array}{c}\text { Control } \\
\text { group }\end{array}$} & \multicolumn{2}{|c|}{ Acute Fasciola patients } & \multicolumn{2}{|c|}{ Chronic Fasciola patients } \\
\hline & & $\begin{array}{l}\text { Before } \\
\text { treatment }\end{array}$ & $\begin{array}{c}\text { After } \\
\text { treatment }\end{array}$ & $\begin{array}{c}\text { Before } \\
\text { treatment }\end{array}$ & $\begin{array}{c}\text { After } \\
\text { treatment }\end{array}$ \\
\hline n & $(10)$ & $(6)$ & $(6)$ & $(15)$ & $(15)$ \\
\hline Range & $20.49-51.22$ & $25-27.32$ & $27-28$ & $23.59-34.14$ & $23.28-43.46$ \\
\hline \multirow[t]{6}{*}{$\begin{array}{l}\text { Mean + } \\
\text { S.E.M }\end{array}$} & $33.47 \pm 2.41$ & $26.40 \pm 0.35$ & $27.50 \pm 0.14$ & $28.18 \pm 0.62$ & $32.83 \pm 1.19$ \\
\hline & & $\mathbf{P}=$ & 015 & & 000 \\
\hline & & $=0.043 \triangleleft \downarrow$ & & & \\
\hline & & $P=\mathbf{0 . 0 8 0}$ & & & \\
\hline & $\diamond$ & $\mathbf{P}=\mathbf{0 . 0 1 9}$ & & & \\
\hline & & $P=0.795$ & & & \\
\hline
\end{tabular}

\section{The results are expressed in $\mathrm{mg} \%$.}

Table (VI): Erythrocyte glutathione s-transferase specific activity of controls and patients infected with Fasciola before and after treatment with Egaten.

\begin{tabular}{|c|c|c|c|c|c|}
\hline \multirow{3}{*}{ Pus } & \multirow{3}{*}{$\begin{array}{l}\text { Control } \\
\text { group }\end{array}$} & & & \multirow{2}{*}{\multicolumn{2}{|c|}{ Chronic Fasciola patients }} \\
\hline & & \multicolumn{2}{|c|}{ Acute Fasciola patients } & & \\
\hline & & $\begin{array}{c}\text { Before } \\
\text { treatment }\end{array}$ & $\begin{array}{c}\text { After } \\
\text { treatment }\end{array}$ & $\begin{array}{c}\text { Before } \\
\text { treatment }\end{array}$ & $\begin{array}{c}\text { After } \\
\text { treatment }\end{array}$ \\
\hline $\mathrm{n}$ & (10) & (6) & (6) & $(15)$ & $(15)$ \\
\hline Range & $28.2-83.17$ & $181.32-572.54$ & $40.41-53.88$ & $119.68-403.04$ & $22.32-98.43$ \\
\hline \multirow[t]{6}{*}{$\begin{array}{l}\text { Mean } \pm \\
\text { S.E.M }\end{array}$} & $63.61 \pm 7.72$ & $274.56+68.66$ & $45.56+1.88$ & $233.52 \pm 32.23$ & $56.61 \pm 5.27$ \\
\hline & & \multicolumn{2}{|c|}{$\diamond \mathrm{P}=0.022 \longrightarrow \downarrow$} & \multicolumn{2}{|c|}{$\mathrm{P}=\mathbf{0} .000$} \\
\hline & & $\mathbf{P}=\mathbf{0 . 0 0 1} \uparrow$ & & & \\
\hline & & $P=0.099$ & & & \\
\hline & $\diamond$ & $P=0.000$ & & & \\
\hline & $\diamond$ & $P=0.445$ & & & \\
\hline
\end{tabular}

The results are expressed in $\mathrm{U} / \mathbf{g} \mathrm{Hb}$. 
Table (VII): Erythrocyte catalase specific activity of controls and patients infected with Fasciola before and after treatment with Egaten.

\begin{tabular}{|c|c|c|c|c|c|}
\hline & \multirow{2}{*}{$\begin{array}{l}\text { Control } \\
\text { group }\end{array}$} & \multicolumn{2}{|c|}{ Acute Fasciola patients } & \multicolumn{2}{|c|}{ Chronic Fasciola patients } \\
\hline & & $\begin{array}{c}\text { Before } \\
\text { treatment }\end{array}$ & $\begin{array}{c}\text { After } \\
\text { treatment }\end{array}$ & $\begin{array}{c}\text { Before } \\
\text { treatment }\end{array}$ & $\begin{array}{c}\text { After } \\
\text { treatment }\end{array}$ \\
\hline $\mathbf{n}$ & $(10)$ & $(6)$ & $(6)$ & $(15)$ & $(15)$ \\
\hline Range & $\begin{array}{c}2104.18- \\
6704.42 \\
\end{array}$ & $\begin{array}{c}3613.22- \\
5480.37\end{array}$ & $\begin{array}{c}4625.56- \\
7692.65 \\
\end{array}$ & $\begin{array}{l}1619.81- \\
4395.81\end{array}$ & $\begin{array}{c}3699.63- \\
6851.56\end{array}$ \\
\hline \multirow[t]{5}{*}{$\begin{array}{l}\text { Mean } \pm \\
\text { S.E.M }\end{array}$} & $\begin{array}{c}3434.62 \pm \\
430.70\end{array}$ & $\begin{array}{c}4466.12 \pm \\
248.70 \\
\end{array}$ & $\begin{array}{c}6655.73 \pm \\
449.12 \\
\end{array}$ & $\begin{array}{c}2996.71 \pm \\
180.21 \\
\end{array}$ & $\begin{array}{c}4802.78 \pm \\
206.24\end{array}$ \\
\hline & & \multicolumn{2}{|c|}{$\mathrm{P}=0.003$} & \multicolumn{2}{|c|}{$\mathrm{P}=0.000$} \\
\hline & \multicolumn{2}{|c|}{$P=0.105$} & & & \\
\hline & & $P=0.000$ & & & \\
\hline & & $\mathrm{P}=\mathbf{0 . 3 0 0}$ & & & \\
\hline & & $P=0$. & & & \\
\hline
\end{tabular}

The results are expressed in $\mathrm{U} / \mathrm{gHb}$. 
Table (VIII): Hemoglobin content, hematocurit values, red blood cell count and eosinophilic (\%) in controls and patients with acute and chronic fascioliasis before and after treatment with Egaten.

\begin{tabular}{|c|c|c|c|c|c|}
\hline \multirow[b]{2}{*}{$\mathbf{N}$} & \multirow[b]{2}{*}{$\begin{array}{l}\text { Control } \\
\text { (10) }\end{array}$} & \multicolumn{2}{|c|}{ Acute fascioliasis } & \multicolumn{2}{|c|}{ Chronic fascioliasis } \\
\hline & & $\begin{array}{c}\text { Before } \\
\text { treatment (6) }\end{array}$ & $\begin{array}{c}\text { After } \\
\text { treatment } \\
(6) \\
\end{array}$ & $\begin{array}{c}\text { Before } \\
\text { treatment } \\
(15) \\
\end{array}$ & $\begin{array}{c}\text { After } \\
\text { treatment } \\
(15) \\
\end{array}$ \\
\hline $\begin{array}{l}\text { Hemoglobin content }(\mathbf{g} / \mathbf{d l}) \\
\text { Range } \\
\text { Mean } \pm \mathrm{SEM}\end{array}$ & $\begin{array}{c}12.30-15 \\
13.44 \pm 0.26\end{array}$ & $\begin{array}{c}10-11.90 \\
10.99 \pm 0.27 *\end{array}$ & $\begin{array}{c}12.10-13.50 \\
12.76 \pm 0.18^{* *}\end{array}$ & $\begin{array}{c}9.10-12.50 \\
11.35 \pm 0.25^{*}\end{array}$ & $\begin{array}{c}12.30-14.50 \\
13.29 \pm 0.19^{* *}\end{array}$ \\
\hline $\begin{array}{l}\text { Hematocrit values }(\%) \\
\text { Range } \\
\text { Mean } \pm \text { SEM }\end{array}$ & $\begin{array}{c}34-45 \\
39.90 \pm 0.99\end{array}$ & $\begin{array}{c}33-36 \\
34.83 \pm 0.48 *\end{array}$ & $\begin{array}{c}38-40 \\
39.0 \pm 0.37\end{array}$ & $\begin{array}{c}27-38 \\
34.20 \pm 0.76^{*}\end{array}$ & $\begin{array}{c}35-45 \\
39.73 \pm 0.76\end{array}$ \\
\hline $\begin{array}{c}\text { RBCs count }\left(\mathbf{M} / \mathbf{m m}^{\mathbf{3}}\right) \\
\text { Range } \\
\text { Mean } \pm \mathrm{SEM} \\
\end{array}$ & $\begin{array}{l}4.25-5.17 \\
4.69 \pm 0.10 \\
\end{array}$ & $\begin{array}{c}3.60-3.85 \\
3.72 \pm 0.03 * \\
\end{array}$ & $\begin{array}{c}4.38-4.66 \\
4.53 \pm 0.04 * * \\
\end{array}$ & $\begin{array}{c}3.50-4.51 \\
4.03 \pm 0.06^{*}\end{array}$ & $\begin{array}{c}4.10-5.70 \\
4.64 \pm 0.10 * * \\
\end{array}$ \\
\hline $\begin{array}{l}\text { Eosinophiliccount }(\mathbf{\%}) \\
\text { Range } \\
\text { Mean } \pm \text { SEM } \\
\end{array}$ & $\begin{array}{c}0-5 \\
3.20 \pm 0.55 \\
\end{array}$ & $\begin{array}{c}17-33 \\
24 \pm 2.13 * \\
\end{array}$ & $\begin{array}{c}4-10 \\
6.17 \pm 0.87 * \\
\end{array}$ & $\begin{array}{c}4-20 \\
10.27 \pm 0.95 *\end{array}$ & $\begin{array}{c}2-8 \\
4.27 \pm 0.42 * *\end{array}$ \\
\hline
\end{tabular}

*Significant when compared with control.

** Significant when compared with that before treatment. 
Table (IX): Liver function tests in controls and patients with acute and chronic fascioliasis before and after treatment with Egaten.

\begin{tabular}{|c|c|c|c|c|c|}
\hline \multirow[b]{2}{*}{$\mathbf{N}$} & \multirow[b]{2}{*}{$\begin{array}{l}\text { Control } \\
\text { (10) }\end{array}$} & \multicolumn{2}{|c|}{ Acute fascioliasis } & \multicolumn{2}{|c|}{ Chronic fasciloiasis } \\
\hline & & $\begin{array}{c}\text { Before } \\
\text { treatment } \\
(6)\end{array}$ & $\begin{array}{c}\text { After } \\
\text { treatment } \\
(6)\end{array}$ & $\begin{array}{c}\text { Before } \\
\text { treatment } \\
(15)\end{array}$ & $\begin{array}{c}\text { After } \\
\text { treatment } \\
(15)\end{array}$ \\
\hline $\begin{array}{l}\mathbf{A L T}(\mathbf{U} / \mathbf{L}) \\
\text { Range } \\
\text { Mean } \pm \text { SEM }\end{array}$ & $\begin{array}{c}10-32 \\
20.11 \pm 1.74\end{array}$ & $\begin{array}{c}14-133 \\
69.37 \pm 15.48^{*}\end{array}$ & $\begin{array}{c}10-29 \\
18.0 \pm 2.56^{* *}\end{array}$ & $\begin{array}{c}7-49 \\
18.80 \pm 2.77\end{array}$ & $\begin{array}{c}8.42 \\
18.60 \pm 2.11\end{array}$ \\
\hline $\begin{array}{c}\text { AST (U/L) } \\
\text { Range } \\
\text { Mean } \pm \text { SEM }\end{array}$ & $\begin{array}{c}14-38 \\
22.88 \pm 2.36\end{array}$ & $\begin{array}{c}19-87 \\
45.50 \pm 9.33 *\end{array}$ & $\begin{array}{c}13.19 \\
16.39 \pm 0.80^{* *}\end{array}$ & $\begin{array}{c}11-47 \\
24.83 \pm 1.91\end{array}$ & $\begin{array}{c}10-47 \\
21.10 \pm 2.04\end{array}$ \\
\hline $\begin{array}{l}\mathbf{A L P}(\mathbf{U} / \mathbf{L}) \\
\text { Range } \\
\text { Mean } \pm \text { SEM }\end{array}$ & $\begin{array}{c}112-303 \\
159.60 \pm 18.06\end{array}$ & $\begin{array}{c}153-405 \\
296.33 \pm 33.44^{*}\end{array}$ & $\begin{array}{c}72-186 \\
129.17 \pm 14.72 * *\end{array}$ & $\begin{array}{c}94-437 \\
244.20 \pm 21.77 *\end{array}$ & $\begin{array}{c}63-275 \\
160.13 \pm 14.1 \\
8 * *\end{array}$ \\
\hline $\begin{array}{c}\text { Billirubin (mg/dl) } \\
\text { Range } \\
\text { Mean } \pm \text { SEM }\end{array}$ & $\begin{array}{c}0.4-0.7 \\
0.57 \pm 0.03\end{array}$ & $\begin{array}{c}0.6-0.8 \\
0.73 \pm 0.03 *\end{array}$ & $\begin{array}{c}0.5-0.6 \\
0.53 \pm 0.02 * *\end{array}$ & $\begin{array}{c}0.5-1.2 \\
0.78 \pm 0.04^{*}\end{array}$ & $\begin{array}{c}0.4-0.7 \\
0.59 \pm 0.02 * *\end{array}$ \\
\hline
\end{tabular}

* Significant when compared with control.

** Significant when compared with that before treatment. 


\section{DISCUSSION}

The present study indicated that infection with fasciola, was accompanied by changes in the oxidative abilities of erythrocytes, that was manifested by a significant decrease in the activities of the main anti-oxidant enzymes, SOD, GP $\mathrm{X}_{\mathrm{X}}$, GR and G6-PD and in the content of the non enzymatic anti oxidant GSH. The only exception from this pattern was increased activity of GST, and unchanged activity of CAT.

Previous studies on rats infected with F.hepatica showed that the antioxidant capabilities of liver enzymes (SOD, GPx, GR) were reduced, GSH content showed significant depletion as a result of infection ${ }^{(25)}$.

Results of the present study support the study of Rehim (2003) ${ }^{(26)}$, which revealed a significant depletion in the erythrocyte GSH content as well as GPx and SOD activities in patients with acute and chronic fascioliasis.

SOD, is the main anti-oxidant enzyme of the cell, responsible for scavenging the super oxide radical. With infection, its level was decreased and the super oxide radicals are thus expected to be elevated. Superoxide anions could cause oxidation of critical $\mathrm{SH}$ groups in proteins and possibly induce peroxidation of lipids in the membrane of the RBCs, causing lysis of the red cell membrane. ${ }^{(27-29)}$ Moreover, some of the hemoglobin become oxidized to methemoglobin that does not build or transport $\mathrm{O}_{2}$. Heme may also be released, it reacts with $\mathrm{O}_{2}$ and $\mathrm{H}_{2} \mathrm{O}_{2}$ to produce $\mathrm{OH}^{\bullet}$ and $\operatorname{ROS}^{(30)}$

RBCs CAT is protected from prooxidant mediated inactivation by associated NADPH. G6-PD is the main source of NADPH generation. G6-PD was significantly inhibited in patient groups. Accordingly a decrease in catalase activity is expected. Yet, in the present study, the level of CAT in the oxidatively stressed erythrocyte did not show significant difference when compared with the control level. That finding could be explained according to Cooper et al (1972) ${ }^{(31)}$ who stated that G6-PD deficiency lead to depletion of NADPH but has a smaller effect on $\mathrm{NADH}$, the latter might prevent inactivation of CAT in the erythrocytes. The unchanged acticity of CAT might also be attributed two its low affinity to $\mathrm{H}_{2} \mathrm{O}_{2}$. ${ }^{(32)}$

GSH is believed to function as an important redox buffer. It protects cell membranes from oxidative damage and helps to maintain the $\mathrm{SH}$ group of many proteins in the reduced form. In fasciola patients, the erythrocyte level of GSH was found to be low compared to the level in controls. That finding reflects an increase in free radical production at a rate that might exceed the detoxifying ability of GSH. ${ }^{(33)}$

The decreased level of GSH may be connected with enhanced oxidation of glytathione disulphide (GSSG), catalyzed by free radicals. Moreover, aldehydes generated during lipid peroxidation may form a conjugate with GSH, leading to significant decrease in cellular GSH. ${ }^{(34,35)}$

GPx a selenium containing protein, reduces $\mathrm{H}_{2} \mathrm{O}_{2}$ and various hydro peroxides using GSH as a reducing agent. ${ }^{(36,37)}$ That enzyme showed decreased activity in infected patients, a finding which might be explained by the low content of GSH 
that acts as a substrate and decreased co-factor of $\mathrm{GP}_{\mathrm{X}}{ }^{(\mathbf{3 8})}$ Enzyme inactivation may as well be explained according to Kinter and Robert (1996) by the fact that 4-hydroxy non-enal (4 NHE), the aldehyde generated during lipid peroxidation, reacts with selenium in the active site of $\mathrm{GP}_{\mathrm{X}}$ and inactivates the enzyme. ${ }^{(35)}$ Moreover, non specific oxidation of the susceptible cysteine $\mathrm{SH}$ group adjacent to the selenol group appears to cause irreversible inactivation of the enzyme. ${ }^{(39)}$

GSTs play a central role in human detoxification process. They catalyze the conjugation of GSH to toxic products that may be easily excreted. GST activity was elevated in patients with fascioliasis. The elevation is of interest, since mature erythrocytes are incapable of protein synthesis, so, enzyme activation seems not to reside on protein expression but it could be caused by a favourable conformational change following the oxidant insult. ${ }^{(\mathbf{4 0 , 4 1 )}}$

G6-PD is involved in the generation of NADPH which is indispensable for biosynthesis of GSH. ${ }^{(42,43)}$ A decrease of G6-PD was encountered in all patient groups and this was expected to participate in causation of chronic hemolysis of erythrocytes.

Three months after Egaten treatment, the level of cell antioxidants was restored and became near or within the limits of the normal range.

Elevated levels of ALT and AST in acute phase of fascioliasis could be considered secondary to extensive destruction of the liver parenchyma and to association with some degrees of hepatic necrosis in some areas caused by the penetrating fluke. ${ }^{(25,44)}$

Elevated level of ALP activity in acute stage may be due to hepatic damage and or increased permeability of the cell due to irritation by toxic metabolites of the worms and eggs. In chronic infection the elevation could be attributed to the mechanical obstruction of the bile duct and toxic action of the parasites leading to hyperplasia of the biliary epithelium with failure to excrete the enzyme in the bile, accordingly it is raised in plasma. $^{(45)}$ These results were confirmed by the elevated level of bilirubin in plasma of patients of both phases of infection.

In both animal and human infection with fascioliasis, anemia was reported as one of the most characteristic symptoms. Anemia could be a result of the fluke which is a blood feeder, hemorrhage that occurs from the erosion of the biliary epithelium due to infection, toxic substances released by the fluke ${ }^{(46,47)}$ that affect the piturity gland leading to reduction in thyrotrophic and adrenocorticoid hormones which in turn leads to reduction in the rate of erythopoiesis, ${ }^{(48)}$ reticulocytes that are increased in the periportal blood and shortens the half life of red blood cells. ${ }^{(49,50)}$

In addition, the decline in G6-PD activity noticed in the current study leads to lack of reduced GSH necessary to detoxify ROS. All these findings may explain the anemia detected in the present study that was diagnosed by reduction of $\mathrm{Hb}$ concentration, red blood cell count and hematocruit value. Also, cross linkages of sulfhydral groups occur 
both in hemoglobin and membrane. Heinz bodies that contribute to the rigidity of the red cell membrane resulting in their early removal from the circulation. ${ }^{(51)}$ After 3 months of Egaten treatment, the $\mathrm{Hb}$ concentration, red blood cell count and hematocruit percent regained their normal level denoting that Egaten has beneficial value in restoring the $\mathrm{Hb}$ level and correcting the anemia induced by fascioliasis.

Increased eosinophilic percent is in consistent with previous study by Hishmat et al (1996), ${ }^{(52)}$ it was suggested to be due to the stimulant effect of the parasite antigens specially those of larvae to the $\mathrm{Th}_{2}$ lymphocytes that secrete IL-4 and IL5 , responsible for eosinophilia. ${ }^{(\mathbf{5 3 , 5 4})}$

Eosinophilic percent reached normal values by the end of three months post treatment in chronic fascioliasis. In acute fascioliasis, although the eosinophilic percent was statistically decreased than before treatment but was yet higher than control level.

Conclusively, Egaten has cured all cases of fascioliasis whether in the acute or chronic stage; it has thus abolished the effect of the parasite on the different anti-oxidant enzymes. The drug itself was safe and did not induce any insult.

\section{REFERENCES}

1. Andrews SJ. The life cycle of Fasciola hepatica. In: Fasciolosis. Dalton JP (ed) CAB International 1999; pp. 1-30.

2. Stewart GL, Shupe K, Kin I. Antibody-dependent neutrophilmediated killing Achantamoeba castellani. Int. J. Parasitol., 1994; 24: 739-42.

3. Abou Basha LM, Fadali GA, Nour BM, Abdalla MS. Uncommon complications of human fascioliosis in Alexandria. J. Egypt. Soc. Parasitol., 1989; 19: 743-9.

4. Kumapatilake LM, Ferrante A, Robinson BS, Jaeger T, Poulos A. Enhacement of neutrophilmediate killing of Plasmodium falciparum asexual blood forms by fatty acids: importance of fatty acid structure. Infect. Immun., 1997; 65: 4152-7.

5. Kotze AC, Mc Clure SJ. Haemonchus contortus utilise catalase in defense against exogenous hydrogen peroxide in vitro. Int. J. Parasitol., 2001; 31: 1563-71.

6. Mulholland CW, EL Wood PC, Davis A, Thurnham DI, Kennedy O, Coulter J, Fehily A, Strain JJ. Antioxidant enzymes, inflammatory indices and lifestyle factors in older men: a cohort analysis. Q. J. Med., 1999; 92: 579-85.

7. Ha HC, Sirisosma NS, Kuppusamy P, Zweier JL, Woster PM, Casero Jr RA. The natural polyamine spermine functions directly as a free radical scavenger. Proc. Natl. Acad. Sci. (USA) 1998; 95; 11140-5.

8. Kelvin YAD, Goldberg AL. Oxygen radicals stimulate intracellular proteolysis and lipid peroxidation by independent mechanisms in erythrocytes. J. Biol. Chem., 1987; 262: 8220-6.

9. Boray JC, Strong MB, Sghllen baum M, Vonorell M. Abstracts 
$9^{\text {th }}$ Int. Conf. World, Assoc Adv Vet Parasit Budapest July (1981); 1317; pp: 171.

10. Martin L, Bearer B. Evaluation of kato thick smear technique for quantitative diagnosis of helminthes infection. Am. J. Trop. Med. Hyg., 1968; 17: 38291.

11. El-Morshedy H., Farghaly A., Abou Basha L.M, Barakat R. Triclabendazole in the treatment of human fascioliasis: a community based study. East Mediterranean Health J., 1999; 5 :325-33.

12. Wintrobe MM, Lee GE, Bithel TC, Telen MJ, Kaufman RE. Clinical haematology $\left(10^{\text {th }}\right.$ ed $)$ Lea, Febiger Philadelphia 1998; pp: 193-227.

13. Reitmen S, Frankel S. Colorimetric method for the determination of serum glutamic oxaloacetic and glutamic pyruvic transaminases. Am. J. Clin. Pathol., 1957; 28: 56-63.

14. King PRN, King EG. Colorimetric determination of alkaline phosphatase activity. J. Clin. Pathol., 1954; 7: 322-30.

15. Jendrassik L. Determination of total serum bilirubin. Biochem. J., 1938; 297: 81.

16. Marklund S, Marklund G. Involvement of the superoxide anion radical in autooxidation of pyrogallol and convenient assay for superoxide dismutase. Eur. J. Biochem., 1974; 47: 469-74.

17. Beers RF, Sizer IW. A spectrophotometeric method for measuring the breakdown of $\mathrm{H}_{2} \mathrm{O}_{2}$ by catalase. J. Biol. Chem., 1952; 195: 133-40.
18. Beulter E, Duron O, Kelly BM. Improved method for the determination of blood glutathione. J. Lab. Clin. Med., 1986; 61: 882-8.

19. Paliga DE, valentine WN. Studies on the quantitative and qualitative characterization of erythrocyte glutathione peroxidase. J. Lab. Clin. Med., 1967; 70: 158-69.

20. Beutler E. Glutathione reductase. Science 1969; 165: 613-5.

21. Habig WH, Pabst MJ, Jakoby WB. Glutathione S-transferase, the first enzymatic step in mercapturic acid formation. J. Biol. Chem., 1974, 249(22): 7130-39.

22. Bishop C. Assay of glucose-6phasphate dehydrogenase and 6phosphogluconate dehydrogenase in red cells. J. Lab. Clin. Med., 1966; 68: 144-8.

23. Lowry OH, Rosenbrough NJ, Fan AL, Randall RJ. Protein estimation with the folin ciocaltea reagent. J. Biol. Chem., 1951; 193: 448-50.

24. Bauer JD. Hemoglobin: Clinical Chemistry, Theory, Analysis and Correlation. Mosbey 33ed. 1989: 513-7.

25. Kolodziejczyk L, Siemieniuk E, Skrzydlewska E. Antioxidant potential of rat liver in experimental infection with fasciola hepatica. Parasitol. Res., 2005; 96(6): 367-72.

26. Rehim WM, Sharaf IA, Hishmat M, EL-Toukhy MA, Rwash NA, Fouad HN. Antioxidant capacity in Fasciola hepatica patients before and after treatment with triclabendazole alone or in combination with 
ascorbic acid (vitamin C) and tocofersolan (vitamin E). Arzneimittel. for Schung., 2003; 53(3): 214-20.

27. Velker J. Oxygen metabolism and oxygen toxicity. In: Basic medical Biochemistry: A clinical approach, William, Wilkins (ed) USA 1996; PP: 328-40.

28. Baynes J, Dominiczak MH. Antioxidant defenses and reactive oxygen species. In: Principal of Medical Biochemistry. Mosby, New York, Philadelphia 1999; PP: 133-7.

29. Murray RK. Red and white blood cells. In: Harper's Biochemistry $25^{\text {th }}$ eds. Murray RK. Granner DK, Mayes PA, Rodwell VW (eds). appllton and lange, Norwalk, Connecticut/San Mateo, California 1999; pp: 763-79.

30. Kieinveld HA, Swaak AJG, Hack CE, Koster JK. Interaction between oxygen free radicals and proteins. Scand. J. Rheumatol., 1989; 18: 341-52.

31. Cooper MR, DcChatelet LK, McCall CE. Complete deficiency of leukocyte in glucose 6phosphate dehydrogenase with defective bactericidal activity. J. Clin. Invest., 1972; 51: 769-78.

32. Luzzatto L, Testa U. Human erythrocyte glucose 6-phosphate dehydrogenase: structure and function in normal and mutate subjects. In: Current Topics in Hematology. Diomelli S, Yachnin $\mathrm{S}$ (eds), vol 1. Liss, New York 1978; PP: 1

33. Meister A. Glutathione metabolism. Methods Enzymol., 1995; 251: 3-7.

34. Shan YO, Aw TY, Jones DP. Glutathione dependent protection against oxidative injury. Pharm. Therap., 1990; 47: 61-71.

35. Kinter M, Roberts RJ. Glutathione consumption and glutathione peroxidase inactivation in fibroblast cell lines vs 4- hydroxyl-2-nonenal. Free Radic. Biol. Med., 1996; 21: 45762.

36. Raes M, Michiels C, Remacle J. Comparative study of the enzymatic defense systems against oxygen-derived free radicals: the key role of glutathione peroxidase. Free Radic. Biol. Med., 1987; 3: 3-7.

37. Sini F, Maiorino M, BrigeliusFlohe R, Aumann KD, Roveri A, Schomburg D, Flohe $L$. Diversity of glutathione peroxidases. Methods Enzymol., 1995; 252: 38-53.

38. Domingues C, Ruiz E, Gussinye M, Carrascosa A. Oxidative stress at onset and in early stages of type I diabetes in children and adolescents. Diabetes Care 1998; 21: 1736-42.

39. Jones DP, Eklow L, Thor H, Orrenius S. Metabolism of hydrogen peroxide in isolated hepatocytes: relative contributions of catalase and glutathione peroxidase in decomposition of endogenously generated hydrogen peroxide. Arch. Biochem. Biophys., 1981; 210: 505-16.

40. Tozzi G, Nuccetelli M, lo Bello M, Bernardini S, BEllincampi L, Ballerini S, Gaeta LM, casalic C, Pastore A, Federici G, Bertini E, Piemonte F. Antioxidant enzymes in blood of patients with Friedreich's ataxia. 
Arch. Dis. Child., 2002; 86: 37680.

41. Raijmakers MTM, Steegers EAP, Peters WHM. Glutathione s-transferases and thiol concentrations in embryonic and early fetal tissues. Human reproduction 2001; 16: 2445-50.

42. Efferth T, Osieka R, Beutler E. Molecular characterization of a German of glucose 6-phosphate dehydrogenase deficiency (G6PD Achen). Blood Cell. Mol. Dis., 2000; 26: 101-4.

43. Yilman H, Ciftci M, Beydemir S, Bakan E, Kufrevioglu OI. Purification of glucose 6phosphate dehydrogenase from chicken erythrocytes and investigation of some kinetic properties. Prep. Biochem. Biotech., 2002; 32: 287-301

44. Mansour NS, Yousef FG, Michail EM, Boctor FM. Use of partially purified Fasciola gigantica worm antigen in serological diagnosis of human fascioliasis in Egypt. Am. J. Trop. Med. Hyg., 1983; 32: 550-4.

45. Hassounah OA, Wayoumy As, Abd El-wahab MM. Studies on the effect of acute doses of indomethacin (prostaglandins inhibitor) during induced liver failure. J. Egypt. Soc. Parasitol., 1995; 25: 443-52.

46. Wei D. Fasciola and fascioliasis. In: Chinese Medical Encyclopaedia, parasitology and parasitic diseases. Wua Z, Mao J (eds) Shanghai: Shanghai publishing House for science and Technology 1984; PP: 67-9.

47. Argona R, Riancho J, Salesa L, Gonzalez M. Fascioliasis on developed countries: A review of classic and aberrant forms of the disease. MedicineBaltimore 1995; 74: 13-32.

48. Grafts RC, Meineke HA. Influence of the pituitary on haemopoiesis. A J. Clin. Nut., 1957; 5: 453.

49. Mahfouz M, Fahmy L, Abd ElTawab S, El- Sewedy S, Farag H, Abd El-Rehim. Effect of Fasciola on human erythrocyte membrane lipids. J. Med. Res. Inst., 1995; 16: 58-64.

50. Chen MG, Mott KE. Progress in assessment of morbidity due to Fasciola hepatica infection: a review of recent literature. Trop. Dis. Bull., 1990; 87: R1-R38

51. Mccafrey R, Halsted $C$, Wakab M, Robertson R. Chloramphenicol-induced hemolysis in caucasin G6PD deficiency. Ann. Int. Med., 1971, 74: 722-6.

52. Hishmat MGA, Abow El Hoda MM, El Shazly M. Triclabendazole in the treatment of human fascioliais. International Conference on Health Environment and Development Alexandria 1996; October 14-7.

53. Abou Basha LM, Barakat MK, Abou El Hoda M. Blood histamine IgE in human fascioliasis before and after bithionol and dehydroemetine treatment. Bull Alex Fac Med 1994; 6: 1482-7.

54. Stitt AW, Fairweather I. The effect of triclabendazole on protein synthesis by the liver fluke, Fasciola hepatica. Int. J. Parasitol., 1995; 25: 421-9. 


\section{مقدرة مزيلات السمية ومضادات الأكسدة فى كرات الام الحمراء فى حالات المتورقة الكبدية: تأثير عقار الإيجاتين \\ سامبة عبد المنعم عبيد* ، هدى فهمى فرج"* ، أمانى إبراهيم بوسف" ،

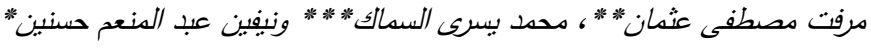

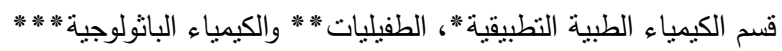 \\ معهد البحوث الطبية، جامعة الإسكندرية}

إن إصابة الإنسان بالمتورقة الكبدية قد تم رصدها فى العديد من البلدان كما تم رصدها أيضاً فى مصر.

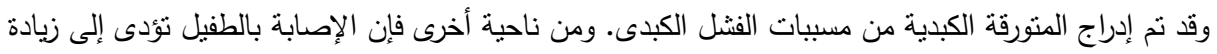

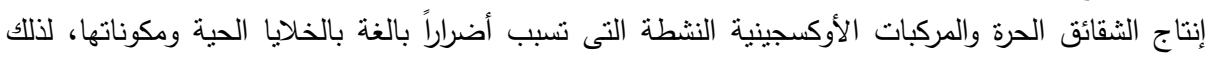
فالجسم لله استراتيجية لتقليل التلف الناتج من التعرض لهذه الثقائق الحرة ومن أهم وسائل الدفاع أنزيمات إزالة

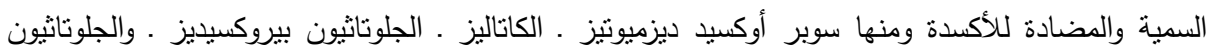

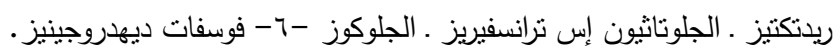

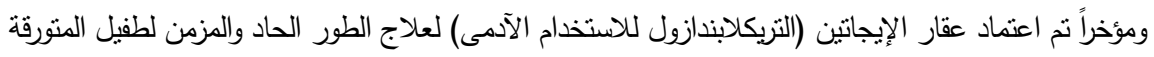

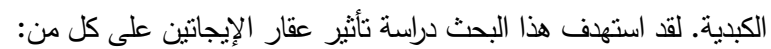

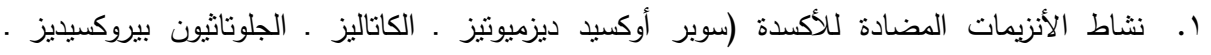

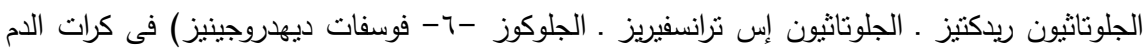

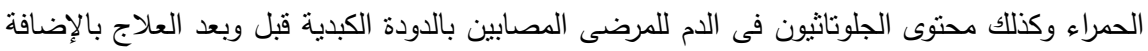

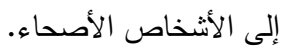
r. ب. و وظائف الكبد قبل وبعد العلاج.

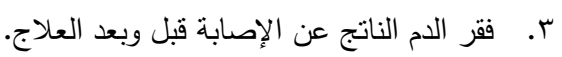

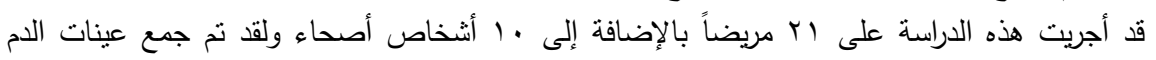
الخاصة بالدراسة من المجموعات الآتية: 1- المجموعة الأولى: ستة مرضى بداء المتورقة الكبدية فى المرحلة الحادة. r- المجموعة الثانية: خمسة عشرة مريضاً بداء المتورقة الكبدية فى المرحلة المزمنة. تم إعطاء العقار بجرعة • ـ مجم/كجم من وزن الجسم لمدة يومين منتاليين. وقد أظهرت الدراسة النتائج

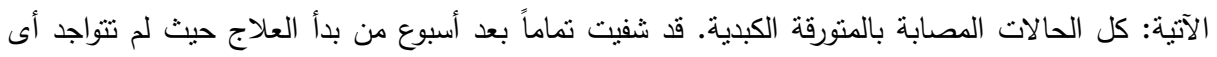

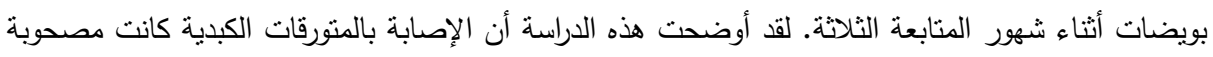

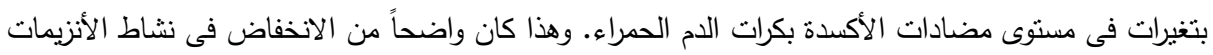

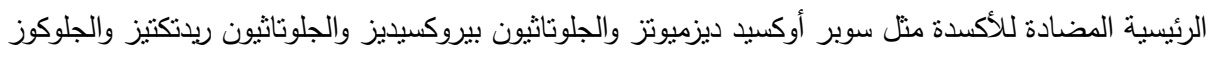

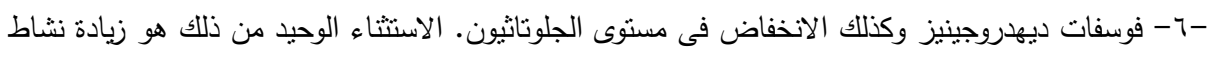

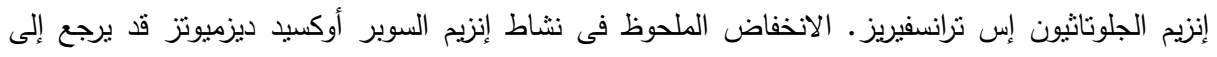


الإنتاج الزائد اللثقائق الحرة الدصاحبة لعملية الالتهاب كرد فعل من العائل للعدوى بالطفيليات. بالنسبة لنشاط

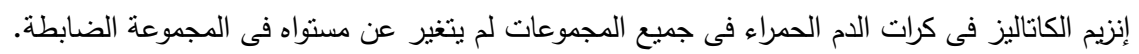

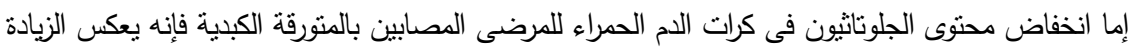

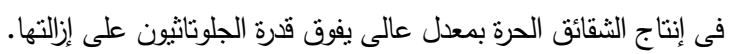

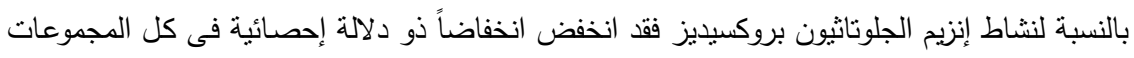

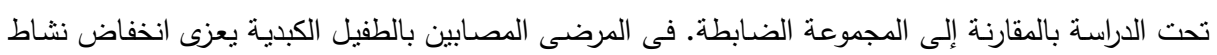

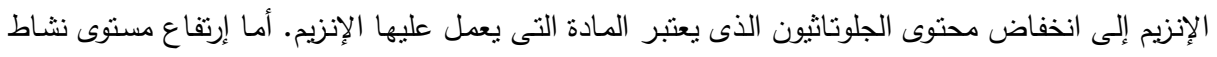

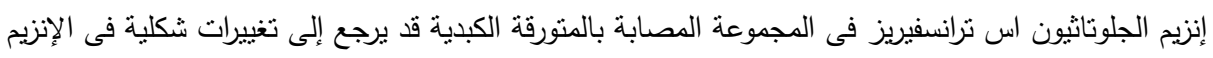

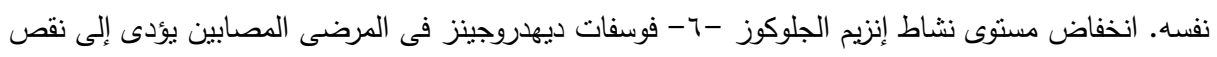

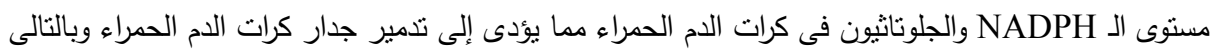
توقع التكسير المزمن لهذه الخلايا.

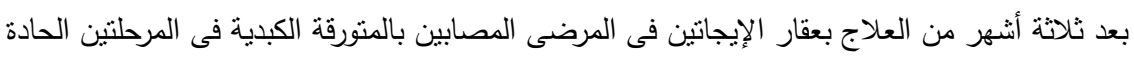

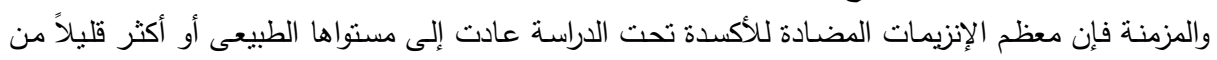

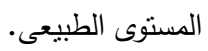

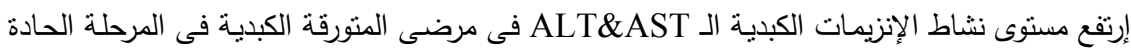

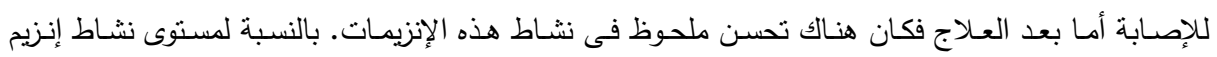

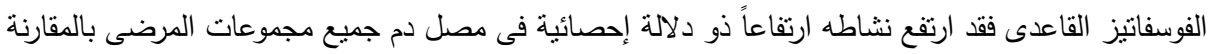

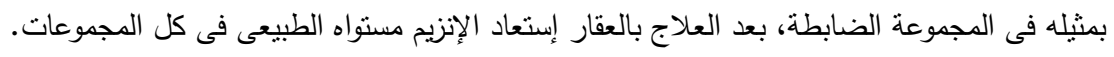

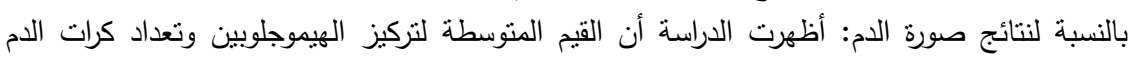

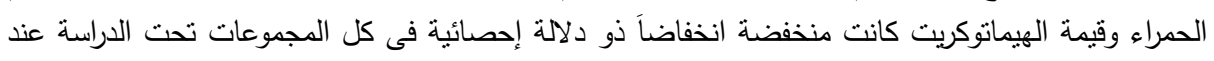

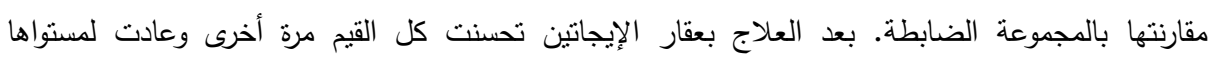
أظهرت الدراسة أن القيم المتوسطة لكرات الدم الدحبة للإيوسين فى كل المجموعات تحت الدراسة كانت مرتفعة

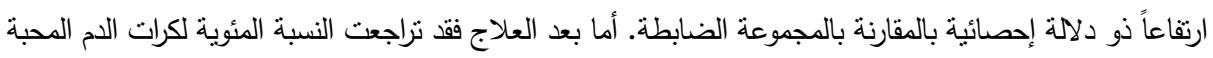
للإيوسين إلى معدلاتها الطبيعية فى الطور الحاد.

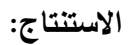

ا •. أن الإصـابة بداء المتورقة الكبدية قد أدى إلى انخفاض نشاط معظم الإنزيمات المضادة للأكسدة تحت

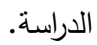
r. أن عقار الإيجاتين قد أثبت كفاءة عالية فى علاج حالات الإصابة بداء المتورقة الكبدية بمرحلتيها الحادة

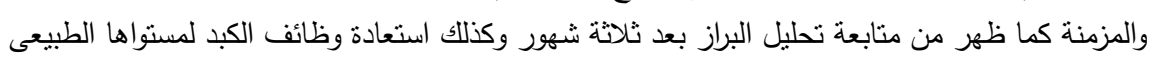

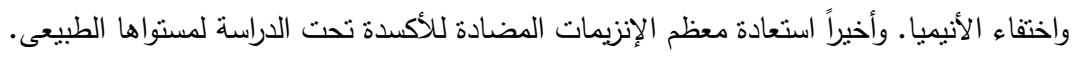

